\title{
INTERDISCIPLINARY CONTEXT OF SOCIAL DEVIATION PREVENTION IN SCHOOL ENVIRONMENT
}

\author{
Václav Bĕlík, Stanislava Hoferková
}

\begin{abstract}
The article analyses the interdisciplinary context of social deviation prevention, particularly in school environment. The article first defines the concept of prevention, describing its possible definitions and classifications including its interdepartmental and interdisciplinary context. The authors focus on the delimitation of the issue of prevention in relation to pedagogy, as they perceive the issue of prevention as a pedagogical/socially pedagogical category. They also notice the overlap of the issue of prevention with other areas - psychology, sociology, medicine, criminology, poenology, addiction research and other branches. The article includes presentation of the results of a small study mapping the issue of prevention from the perspective of school prevention methodists.
\end{abstract}

\section{Keywords}

prevention, preventology, pedagogization of prevention, school, school prevention methodist

\section{Delimitation and Classification of the Issue of Prevention}

The term "prevention" comes from the Latin preavenire, praevenio (Šenková, 2002, p. 262). "The term is often used also in common life and we can define it as a set of measures to prevent an undesirable phenomenon like diseases, drug addictions, crimes, accidents, failure at school, social conflicts, etc." (Prague Centre of PP, 2015). Radimecký (2012) presents an interesting perspective relying upon splitting the word "prevent" into 
its prefix "pre-" and root "-event-". So the meaning of the term can be perceived as unified and clear. Pedagogy understands prevention in compliance with this meaning. The pedagogical dictionary written by Průcha, Walterová and Mareš (2013) describes prevention as a set of measures aimed at prevention of undesirable phenomena, particularly diseases, damages, socially pathological phenomena, and Miovský (2010, p. 24) adds that "it includes all types of upbringing, educational, health care, social or other interventions aimed at prevention of occurrence of risk behaviour, forestalling its further progression, mitigating the existing forms and manifestations of risk behaviour or helping to solve its consequences."

The content of the concept of prevention covers the issue of forestalling risk behaviours. But in practice, it is often confused with the content of the concept of therapy - i.e. solution of problems that have emerged already. We can see the issue of prevention in many different scientific disciplines. The concept is often used for example by medicine that defines prevention as a set of social and health measures aimed at forestalling health damage, origination of diseases and lasting consequences. We can find prevention also in the area of civil law. The prevention is aimed at forestalling conflict to avoid their solution by court decision. (Kraus, Hroncová et al., 2010)

Specialized literature most frequently classified risk behaviour prevention into primary, secondary and tertiary prevention. Most authors mention this classification in relation to prevention of drug addictions. In view of the focus of this article, we will mention the classification from general perspective that includes all risk behaviour types:

1. Primary prevention includes all activities aimed at the whole population and implemented in order to forestall risk behaviours (Matoušek \& Matoušková, 2011; Strategie MŠMT, 2009).

2. Secondary prevention is aimed at individuals showing increased danger of risk behaviour origination. According to MŠMT (Ministry of Education, Youth and Sport), secondary prevention aims at forestalling "origination, development and persistence of risk behaviour" (Strategy of MŠMT, 2009, p. 9). It is implemented in form of early intervention, consulting and therapy.

3. Tertiary prevention is aimed at persons who have personal negative experience with a specific problem. It should forestall further spreading and recurrence of the problem through resocialization and reintegration.

Primary prevention consists of all activities aimed at forestalling the origination and development of risk behaviour in general population. There are a lot of activities aimed at prevention; therefore this broad concept should be specified in more detail. Programs aimed directly at some of the risk behaviour forms and focused on a specific target group are called specific primary prevention (Miovský, 2010; National Strategy of MŠMT, 2012). The National strategy of prevention of risk behaviours in children and youth within the scope of authority of the Ministry of Education, Youth and Physical Education for 20092012 (hereinafter referred to only as the National strategy of MŠMT (National strategy of 
the Ministry of Education, 2012) describes them verbatim as a "system of activities and services focused on work with the population in which further negative development can be expected, if such activities and services are absent, and aimed at prevention or reduction of its increased occurrence". Specific primary prevention is clearly delimited in time and space. The implementer should have the needs of the target group mapped, a plan prepared and a program preparation elaborated. The program should be evaluated and have a specific context (Miovský, 2010). Miovský (2010) divides the specific primary prevention, in compliance with the Strategy of MŠMT (2009) and later with the National strategy of MŠMT (2013) into three levels:

A. General primary prevention - the target group includes groups of general population, regardless of specific risk groups. The groups are divided only by age and they are larger (e.g. a school class). The programs of general PP try to influence the children's attitudes, values and behaviours.

B. Selective primary prevention - is focused on groups with increased risk of origination of different risk behaviour forms (e.g. children from socially weak families, children with poor school results, behaviour disorders, etc.). It is aimed at strengthening the individuals' social skills, communication competences, mutual relations, etc. The demands on professional qualification of the preventists are higher here as compared to general primary prevention.

C. Indicated primary prevention - precedes secondary prevention. It works with distinctively endangered individuals or with individuals who have already shown the risk behaviour. It is aimed at reducing the frequency of risk behaviour occurrence and at mitigating its consequences.

A second possibility of preventive action consists in non-specific primary prevention. Unlike specific prevention, it does not include the demand on focus on a specific risk behaviour type, and it does not distinguish to what target group it is focused. It includes "all methods and approaches allowing the development of harmonic personality, including the opportunities to develop talents, interests, exercise and sport activities" (Strategy of MŠMT, 2009, p. 9). Through support of meaningful spending of leisure time, the individuals acquire positive social behaviour, healthy life style and develop their personality, which allows forestalling the origination and development of risk behaviour.

\section{Prevention as an interdepartmental and interdisciplinary topic}

The prevention comes under the competence of multiple departments in the Czech Republic. The Ministry of Education, Youth and Physical Education, the Ministry of the Interior or the Ministry of Health can be considered dominant. Other departments participating in the prevention system include the Ministry of Labour and Social Affairs, the Ministry of Justice and the Ministry of Defence that cooperate with superordinate 
authorities (Government Council for Coordination of Anti-drug Policy at the Cabinet Office and the Republic Board for Prevention of Criminality at the Ministry of the Interior all departments with material competence are represented in these authorities). The individual ministries elaborate their strategies or programs in the area of prevention in more detail in separate intra-departmental materials. (Hoferková \& Šimková, 2012) The following part offers a selected list of departmental and supra-departmental documents valid for the relevant periods, concerning the issue of prevention:

- Strategy of prevention of criminality in the Czech Republic for the period of 2012 to 2015.

- National strategy of anti-drug policy for the period of 2010 to 2018.

- National strategy of prevention of violence against children for the period of 20082018.

- National strategy of cybernetic safety of the Czech Republic for the period of 2015 to 2020.

- Strategy of fight against social exclusion for the period of 2011-2015.

- Concept of prevention and solution of the issue of homelessness in the Czech Republic until 2020.

- Concept of fight against extremism for the year 2015.

- Action plan of prevention of domestic and gender-conditioned violence for the years 2015-2018.

- Health 2020 - National strategy of protection and support of health and prevention of diseases (the individual action plans include e.g. the Action plan for creation of interdisciplinary interdepartmental framework of primary prevention of risk behaviour in highly endangered children groups in the Czech Republic, the Action plan for the area of control of tobacco in the Czech Republic for the period of 2015-2018, the Action plan for reduction of alcohol-caused damages in the Czech Republic for the period of 2015-2018, the Action plan for support of exercise for the period of 20152020, the Action plan of right nutrition and eating habits of the population for the period of 2015-2020, the Action plan for prevention of obesity, the Action plan for mental health, etc.).

As the list shows, the issue of prevention is an area appropriated by different scientific disciplines, but in practice also by different professions. It is interesting to view the issue of prevention from the perspective of the disciplines and their graduates involved in this issue in the Czech environment (see Fig. No. 1). The list probably is not complete, but it shows illustratively how the issue can be viewed from different perspectives. For the future, a self-standing discipline should be considered in this context in order to integrate the issue of prevention from different scientific disciplines and to link the respective pieces of knowledge. As the existing experience from other countries indicates, preventology could be such a discipline. 
Fig. No. 1: Multidisciplinarity of preventology

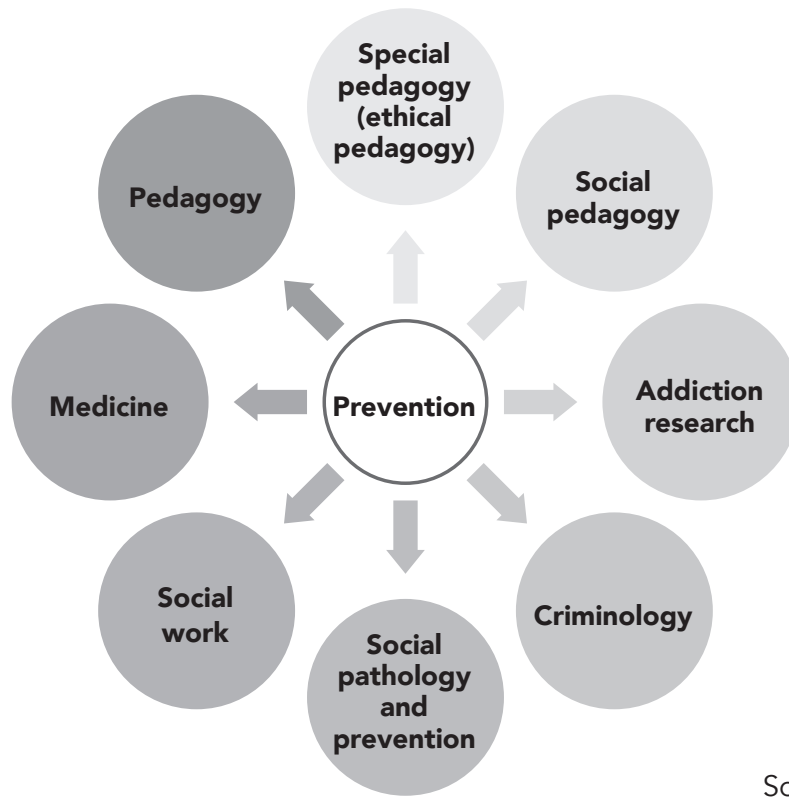

Source: own processing

The disciplines of departure to approach the issue of prevention can include:

- Pedagogy - with focus on the pedagogical reality under use of pedagogical categories (as mentioned above). Particularly the special-pedagogical discipline of ethical pedagogy plays an important role with respect to risk behaviour.

- Sociology - the description of social reality under use of the sociology of the town, family, school, social pathology, methodology, including statistics.

- Psychology - one of its areas, psychology of health, has the issue of prevention in its subject of interest. Knowledge of psychology of personality, social psychology, psychodiagnostics, etc. is important too.

- Medicine - particularly addiction research dealing with the issue of addictions. But the knowledge of somatology, neurology, genetics, psychiatry and other disciplines is important for the prevention workers as well.

- Criminology - as the discipline describing the issue of prevention from the perspective of law including new trends (probation and mediation, early intervention system, etc.).

- Poenology - tertiary prevention, prevention of relapse is the central focus of poenology as a scientific discipline and of penitentiary and post-penitentiary treatment.

- Social work - focuses on prevention of social exclusion of the individual from the civil society. 


\section{Prevention as Key Topic of Pedagogy}

The occurrence of risk behaviour of pupils and students is still unsatisfactory in the school environment. There are different forms of aggressive behaviour, directed not only against pupils, but also against teachers; occurrences of risk behaviour through information technologies are increasing; the situation is alarming also in the area of use of legal habitforming substances (alcohol and tobacco). It is confirmed by the results of studies carried out e.g. by Csémy, Hrachovinová, Starostová and Čáp (2013), Foltová (2012) or Pelcák, Hoferková and Bělík (2015). In the Slovak environment, the same trend is indicated by study findings of Emmerová (2011, 2012), Niklová (2012), Kamarášová (2012), Dulovics (2012) or Nemcová (2009). As Abromaitiené (2004) states, this trend concerns a great part of the European Union countries; a specific situation can be seen in the post-Soviet countries. The above stated reasons lead to focus the attention on prevention in the youngest age categories, primarily in the school environment.

The issue of prevention is a very broad topic. It is covered by a number of non-pedagogical disciplines, although it is evident that it must be viewed from the pedagogical perspective, or from the social-pedagogical perspective, respectively. We can often see the concept of social prevention; therefore, the term "social" should be delimited too:

1. Social in terms of collective; social reality and a process related to more people.

2. Social in terms of existence of liking to other people, positive relation to the society, respect to other people (a condition and process concerning ethics).

3. Social in terms of personal or group attitude, satisfaction existing in mutual coexistence, e.g. proportionality.

It can be therefore stated that "social" can be delimited in general as coexistence with its multiple interpersonal and material relations (Geck, 1971).

As the concept of prevention is used for different activities in different disciplines, it can be explained in different terms. The concept of prevention is commonly used in the pedagogical environment, but it is often erroneously linked with contents acquired from non-pedagogical areas. Prevention is defined as solution of an actually hot issue and presentation or suggestion of strategies for its elimination. The authors in literature often erroneously assume that a phenomenon occurs in the environment under research and they say: "Let's solve it." That shifts the meaning of the actual concept of prevention in practice. Different kinds of therapies, treatment of social diseases in full-blown stage are called prevention. But the actual concept of prevention means forestalling, as we have stated above. That implies building such inner strength in the individual and in the social group (equipping the individual and the group with such competences) to make them resistant against external influences and able to face them actively.

To speak about pedagogization of the issue of prevention, we must clearly delimit which areas of pedagogical reality are crucial for prevention. We understand the concept of pedagogization of prevention as a universal view on the issue across scientific disciplines 
and areas of human life dealing with prevention. (Bělík, 2014) We understand it as specification of preventive upbringing goals, delimitation of standards (key competences for prevention; means that help us to achieve the standard and preventive principles), determination of organization and organizational forms of preventive actions, assessment of preventive activities and work with preventive upbringing methods, or also other pedagogical categories. Within this approach, school prevention should be aimed to:

- Change the interaction relationships at school, replace the authoritative atmosphere by a humanistic-creative atmosphere.

- Support the harmonic development of pupil's personality.

- In the context of current social topics, respond with adequate upbringing steps to problems emerging in the society, including multiculturalism, xenophobia and other problems.

- Prefer healthy life style in all school and after-school activities.

- Create conditions to shape healthy personality and resistance against socially pathological phenomena.

- Bring the pupils up towards responsibility for own decisions.

- Create space at school to help the pupils help their life problems.

- Develop prosocial behaviour and shape the above stated social competences.

\section{Prevention as Seen by School Prevention Methodists}

In 2015, we carried out a small study to map the situation in the area of risk behaviour prevention at selected elementary school of the Region of Hradec Králové. Six school prevention methodists from middle-size elementary schools took part in the study; semistructured interview was chosen as the research method. The following table shows selected results related to risk behaviour and the prevention form (compare Zavoralová, 2015).

Table No. 1: Risk behaviour prevention as seen by school prevention methodists (ES=elementary school)

\begin{tabular}{|l|l|l|l|l|l|}
\hline $\begin{array}{l}\text { Most } \\
\text { frequent } \\
\text { risk } \\
\text { behaviours }\end{array}$ & $\begin{array}{l}\text { Long-term } \\
\text { prevention } \\
\text { programs }\end{array}$ & $\begin{array}{l}\text { Short-term } \\
\text { prevention } \\
\text { activities (talks, } \\
\text { lectures, ...) }\end{array}$ & $\begin{array}{l}\text { Specialized } \\
\text { pedagogical } \\
\text { workers (except } \\
\text { school prevention } \\
\text { methodists and } \\
\text { upbringing } \\
\text { advisors) }\end{array}$ & $\begin{array}{l}\text { Reserves } \\
\text { in implementation } \\
\text { of primary } \\
\text { prevention }\end{array}$ \\
\hline ES1 & $\begin{array}{l}\text { alcohol, } \\
\text { cigarettes, } \\
\text { bullying }\end{array}$ & NO & $\begin{array}{l}\text { authority for social- } \\
\text { legal protection of } \\
\text { children, district } \\
\text { prevention } \\
\text { methodists }\end{array}$ & $\begin{array}{l}\text { part-time school } \\
\text { psychologist }\end{array}$ & $\begin{array}{l}\text { cooperation with } \\
\text { parents, lack of } \\
\text { information at } \\
\text { creating prevention } \\
\text { plan }\end{array}$ \\
\hline
\end{tabular}




\begin{tabular}{|c|c|c|c|c|c|}
\hline & $\begin{array}{l}\text { Most } \\
\text { frequent } \\
\text { risk } \\
\text { behaviours }\end{array}$ & $\begin{array}{l}\text { Long-term } \\
\text { prevention } \\
\text { programs }\end{array}$ & $\begin{array}{l}\text { Short-term } \\
\text { prevention } \\
\text { activities (talks, } \\
\text { lectures, ...) }\end{array}$ & $\begin{array}{l}\text { Specialized } \\
\text { pedagogical } \\
\text { workers (except } \\
\text { school prevention } \\
\text { methodists and } \\
\text { upbringing } \\
\text { advisors) }\end{array}$ & $\begin{array}{l}\text { Reserves } \\
\text { in implementation } \\
\text { of primary } \\
\text { prevention }\end{array}$ \\
\hline ES2 & $\begin{array}{l}\text { truancy, } \\
\text { bullying } \\
\text { (cyber- } \\
\text { bullying) }\end{array}$ & NO & $\begin{array}{l}\text { authority for } \\
\text { social-legal } \\
\text { protection of } \\
\text { children, fire } \\
\text { fighters, nursing } \\
\text { school, pedagogi- } \\
\text { cal-psychological } \\
\text { advisory centre, } \\
\text { non-profit } \\
\text { organizations; } \\
\text { upbringing } \\
\text { concerts }\end{array}$ & & $\begin{array}{l}\text { time and financial } \\
\text { limits }\end{array}$ \\
\hline ES3 & $\begin{array}{l}\text { alcohol, } \\
\text { cigarettes, } \\
\text { bullying, } \\
\text { vandalism }\end{array}$ & NO & $\begin{array}{l}\text { authority for } \\
\text { social-legal } \\
\text { protection of } \\
\text { children, pedagogi- } \\
\text { cal-psychological } \\
\text { advisory centre, } \\
\text { non-profit } \\
\text { organizations; } \\
\text { external courses }\end{array}$ & $\begin{array}{l}\text { special educator, } \\
\text { school } \\
\text { psychologist }\end{array}$ & $\begin{array}{l}\text { insufficient } \\
\text { education } \\
\text { of prevention } \\
\text { implementers }\end{array}$ \\
\hline ES4 & $\begin{array}{l}\text { truancy, } \\
\text { bad rela- } \\
\text { tionships }\end{array}$ & YES & $\begin{array}{l}\text { authority for } \\
\text { social-legal } \\
\text { protection of } \\
\text { children, police, } \\
\text { prison service; } \\
\text { external courses }\end{array}$ & & $\begin{array}{l}\text { more frequent } \\
\text { prevention } \\
\text { activities }\end{array}$ \\
\hline ES5 & $\begin{array}{l}\text { truancy, } \\
\text { bullying, } \\
\text { bad rela- } \\
\text { tionships }\end{array}$ & YES & $\begin{array}{l}\text { authority for } \\
\text { social-legal } \\
\text { protection of } \\
\text { children, peda- } \\
\text { gogical-psycho- } \\
\text { logical advisory } \\
\text { centre; external } \\
\text { courses }\end{array}$ & & financial limits \\
\hline ES6 & $\begin{array}{l}\text { smoking, } \\
\text { bad rela- } \\
\text { tionships, } \\
\text { vulgarisms }\end{array}$ & YES & $\begin{array}{l}\text { authority for } \\
\text { social-legal } \\
\text { protection of } \\
\text { children, } \\
\text { physician, fire } \\
\text { fighters; external } \\
\text { courses }\end{array}$ & & financial limits \\
\hline
\end{tabular}


The results of the study have confirmed that the most frequent risk behaviours include truancy, use of habit-forming substances (the school prevention methodists remark that such behaviour type takes place most often out of school and only in some individuals), bullying and generally bad relationships in class groups. Phenomena related to information technologies, particularly cyberbullying start constituting a problem - some teachers admit that they still are not able to work efficiently with such phenomena. We can state that the schools under research approach the preventive programs responsibly and exert considerable initiative in this area. A half of the schools make use of long-term prevention programs; each school also makes use of short-term preventive activities offered primarily by authorities for social-legal protection of children, police, but also by other - governmental and non-governmental - subjects. Most respondents consider important to implement external class courses in order to strengthen the relationships in the class group. All respondents mentioned that some kind of prevention takes place also during common lessons, primarily in civics or family education, health education and natural history.

As for the limits in primary prevention, the school methodists gave very varied answers; nevertheless, their responses coincided in some matters. The schools most frequently face lack of funds, which strongly limits the choice and frequency of preventive activities and programs. Two schools have the preventive area completely supported by the municipal government that has designated funds from its budget. One school is supported by the municipal government only in part, and one draws money from a grant. All the schools mentioned above are concerned whether they will be able to continue the cooperation in the upcoming years, because of financial issues. For some schools, a limiting factor consists also in the time that must be designated for the programs on the expense of the number of lessons of individual subjects. A minimal preventive program becomes another reserve of two schools under research, as they are not familiarized with its form and therefore are not able to compile it with the necessary requisites to make it effective. Other drawbacks perceived by the schools are based on individual experience and personal opinions of school prevention methodists; therefore, they did not come along repeatedly in the interviews. The schools would welcome better cooperation with the parents to achieve compact preventive effect not only on the part of the school. Further, they would appreciate larger offer of educational courses for teachers in the preventive area, with focus on hot topics, for example cyberbullying.

The educational tasks in the area of development of social competences constitute the basic element of social prophylaxis and prevention of all social deviations. But to be able to develop them, the teachers and the school must be prepared to master such tasks. Both formal and informal stipulation of competences pertaining to teachers constitutes an important factor in making the school or the teachers, respectively, to act as an imaginary social indicator of all depravities of the present and as an efficient dissolving agent of potentially emerging problems. At this moment, we do not refer only to teaching competences (Bělík, 2012) but primarily to upbringing and legal competences that will help the teachers considerably to acquire a much higher social prestige and 
to implement their upbringing-educational or also preventive-educational goals. (Bělík \& Kraus, 2011)

\section{Conclusion}

The ways to approach the issue of prevention of social deviations in the Czech school environment are as interdisciplinary as the issue of prevention in itself. Prevention in school environment is in charge of the school preventive system - school direction, upbringing advisor, school prevention methodist, special educator. The issue of prevention involves also the school psychologist, and also the social educator at some schools (mainly schools in the Region of Zlín and in the South Moravian Region that employ social educators within the ESF project). Auxiliary institutions include pedagogical-psychological advisory centres or special pedagogical centres, as well as centres of upbringing care within so called preventive upbringing care.

Prevention consists of a professional discourse of a number of disciplines. Addiction research discusses the issue of prevention in school environment; social work discusses the role of social worker at school. Therefore, we can perceive the issue of prevention as an interdisciplinary - inter-transdisciplinary issue.

\section{References}

Abromaitienè, L. (2004). The Emerging aspects of children's social and educational problems in the new member states EU. Educationline, 1-18.

Akční plán prevence domácího a genderově podmíněného násilí na léta 2015-2018. [Action Plan for the Prevention of Domestic and Gender-based Violence for the Years 2015-2018]. [online]. Accessed 11 November 2015. http://www.vlada.cz/cz/clenovevlady/pri-uradu-vlady/jiri-dienstbier/aktualne/vlada-schvalila-akcni-plan-prevencedomaciho-a-genderove-podmineneho-nasili-na-leta-2015-_-2018-126943/.

Akční plány pro implementaci Národní strategie Zdraví 2020. [Action Plans for the Implementation of the National Strategy for Health 2020]. [online]. Accessed 11 November 2015. http://www.mzcr.cz/verejne/dokumenty/akcni-plany-pro-implementacinarodni-strategie-zdravi-2020_10814_3016_5.html.

Bělík, V. (2014). Pedagogika v prevenci, prevence v pedagogike [Education in Prevention, Prevention in Education]. In T. Raszková (ed.), Acta sociopathologica I. (pp. 7-20). Hradec Králové: Faculty of Education, University of Hradec Králové.

Bělík, V. (2012). Rizikové chování a jeho prevence v terciárním vzdělávání pedagogů [Risk Behaviour and Its Prevention in Tertiary Education of Teachers]. Hradec Králové: Gaudeamus. 
Csémy, L., Hrachovinová, T., Starostová, O., \& Čáp, P. (2013). Agresivní chování ve školách ČR z pohledu učitelů a žáků 2. stupně základních škol. [Aggressive Behavior in Schools in the Czech Republic from the Point of View of Teachers and Pupils of the 2nd Grade of Elementary Schools]. [online]. Accessed 11 November 2015. http://www.vyzkum-mladez. cz/zprava/1411385464.pdf.

Dulovics, M. (2012). Riziko vzniku mediálnych závislostí u žiakov základných a stredných škôl a možnosti ich prevencie z aspektu profesie sociálneho pedagóga. [Risk of Media Dependency in Primary and Secondary Schools and Possibilities of Their Prevention from Aspect of the Profession of Social Pedagogue]. Banská Bystrica: Faculty of Education, Matej Bel University.

Emmerová, I. (2011). Aktuálne otázky prevencie problémového správania u žiakov $\checkmark$ školskom prostředí. [Current Issues of Prevention of Problem Behaviour Among Pupils in the School Environment]. Banská Bystrica: Faculty of Education, Matej Bel University.

Emmerová, I. (2012). Preventívna a sociálno-výchovná práca s problémovými det́mi a mládežou. [Preventive and Social-educational Work with Troubled Children and Youth]. Banská Bystrica: Faculty of Education, Matej Bel University.

Foltová, L. (2012). Souvislost psychických potíži a rizikového chování adolescentů. [Relation between Psychological Problems and Risky Behaviour of Adolescents]. Česká a slovenská psychiatrie [Czech and Slovak Psychiatry], 108(2), 72-79.

Geck, W. (1971). Promotionsordnungen und Grundgesetz [Promotion Orders and Constitution].Köln:AnnalesUniversitatisSaraviensis, Rechts-undwirtschaftswissenschaftliche Abteilung, H. 24.

Hoferková, S., \& Šimková, E. (2012). Systém prevence sociálněpatologických jevů ze strany veřejné správy. [Sociopathic Phenomena Prevention System from the Perspective of Public Administration]. Prevence úrazů, otrav a násilí [Prevention of Injuries, Intoxications and Violence], 8(1), 66-74.

Kamarášová, L. (2012). Aktuálne problémy pri realizácii primárnej prevencie sociálnopatologických javov v školách. [Current Problems in the Implementation of Primary Prevention of Socio-pathological Phenomena in Schools]. Banská Bystrica: Faculty of Education, Matej Bel University.

Koncepce boje proti extremismu pro rok 2015. [Strategy on Struggling Extremism in 2015]. [online]. Accessed 11 November 2015. http://www.mvcr.cz/clanek/extremismusvyrocni-zpravy-o-extremismu-a-strategie-boje-proti-extremismu.aspx.

Koncepce prevence a řešení problematiky bezdomovectví v ČR do roku 2020. [Strategy for Preventing and Tackling Homelessness in the Czech Republic until 2020]. [online]. Accessed 11 November 2015. http://www.mpsv.cz/cs/16156. 
Kraus, B., \& Bělík, V. (2011). Trendy preventivně výchovného působení v současné škole [Trends of Preventive Educational Activities in the Contemporary School]. Prevence úrazů, otrav a násilí [Prevention of Injuries, Intoxications and Violence], 7(1), 62-67.

Kraus, B., \& Hroncová, J. et al. (2010). Sociální patologie [Social Pathology]. Hradec Králové: Gaudeamus.

Matoušek, O., \& Matoušková, A. (2011). Mládež a delikvence: možné př́íčny, struktura, programy prevence kriminality mládeže. [Youth and Delinquency: Possible Causes, Structure, Programs to Prevent Youth Crime]. Prague: Portál.

Miovský, M. et al. (2010). Primární prevence rizikového chování ve školství. [Primary Prevention of Risk Behaviour in Schools]. Prague: SCAN Association.

Národní strategie kybernetické bezpečnosti České republiky na období let 2015 až 2020. [The National Cyber Security Strategy of the Czech Republic for the Period 2015-2020]. [online]. Accessed 11 November 2015. https://www.govcert.cz/cs/informacni-servis/ strategie-a-akcni-plan/.

Národní strategie prevence násilí na dětech v ČR na období 2008-2018. [National Strategy to Prevent Violence against Children in the Czech Republic for the Period 2008-2018]. [online]. Accessed 11 November 2015. http://www.vlada.cz/cz/ppov/rlp/dokumenty/ strategie-prevence-nasili-na-detech/strategie-prevence-nasili-na-detech-59898/.

Národní strategie primární prevence rizikového chování dětí a mládeže na období 2013-2018. [National Strategy for Primary Prevention of Risk Behaviour of Children and Youth for the Period 2013-2018]. [online]. Accessed 11 November 2015. http:// www.kr-kralovehradecky.cz/cz/krajsky-urad/skolstvi/prevence-soc-patologickychjevu/narodni-strategie-primarni-prevence-rizikoveho-chovani-deti-a-mladeze-naobdobi-2013---2018-62422/.

Národní strategie protidrogové politiky na období 2010 až 2018. [National Drug Policy Strategy for the Period 2010-2018]. [online]. Accessed 11 November 2015. http:// www.vlada.cz/cz/ppov/protidrogova-politika/strategie-a-plany/narodni-strategieprotidrogove-politiky-na-obdobi-2010-az-2018-99404/.

Niklová, M. (2012). Sociálny pedagóg ako odborník pre prevenciu sociálno-patologických javov a špecifiká jeho pôsobenia $v$ školskom prostredí. [The Social Educator as a Professional for the Prevention of Socio-pathological Phenomena and the Specifics of His Tenure in the School Environment]. In J. Hroncová \& I. Emmerová et al. Sociálny pedagóg v škole. Zborník z medzinárodného odborného seminára. [The Social Educator in the School. Proceedings of the International Expert Seminar] (pp. 97-110). Bánska Bystrica: Faculty of Education, Matej Bel University. 
Pelcák, S., Hoferková, S, \& Bělík, V. (2015). Smysl pro soudržnost a adherence ke zdravému životnímu stylu u adolescent [Sense of Coherence and Adherence to a Healthy Lifestyle Among Adolescents]. Lifelong Learning - Celoživotní vzdělávání, 5(2), 73-80.

Rizikové chování - prevence [Risk Behavior - Prevention]. [online]. Accessed 11 November 2015. http://www.prevence-Prague.cz/index.php/rizikove-chovani-charakteristiky.

Průcha, J., Walterová, E., \& Mareš, J. (2013). Pedagogický slovník. [Pedagogical Dictionary]. Prague: Portál.

Radimecký, J. et al. (2007). Prevence a adiktologie pro odborníky pracující v ústavní výchově a preventivně výchovné péči: učební podklady ke kurzu. [Prevention and Addictology for Practitioners Working in Institutional Care and Preventive Educational Care: Teaching Materials for the Course]. Prague: Adictology Clinic of the 1st Faculty of Medicine, Charles University and General University Hospital in Prague.

Strategie boje proti sociálnímu vyloučení na období 2011-2015. [Strategy for Struggle Against Social Exclusion for 2011-2015 Period]. [online]. Accessed 11 November 2015. http://www.socialni-zaclenovani.cz/dokumenty/strategie-boje-proti-socialnimuvylouceni/.

Strategie prevence kriminality v České republice na léta 2012 až 2015 [Crime Prevention Strategy in the Czech Republic for 2012-2015 Period]. [online]. Accessed 11 November 2015. http://www.mvcr.cz/clanek/strategie-prevence-kriminality-na-leta-2012-2015.aspx.

Strategie prevence rizikových projevů chování u dětí a mládeže v působnosti resortu školství, mládeže a tělovýchovy na obdobi 2009-2012. [Strategy of Prevention of Risk Behaviour Among Children and Youth]. Prague: Ministry of Education, Youth and Sport of The Czech Republic, 2009.

Šenková, S. (2002). Latinsko-český, česko-latinský slovník. [Latin-Czech, Czech-Latin Dictionary]. Olomouc: Olomouc Publishing.

Výzkum rizikového chování českých dětí v prostredí internetu 2013. [Research on Risk Behavior of Czech Children on the Internet in 2013]. [online]. Accessed 11 November 2015. http://www.e-bezpeci.cz/index.php/veda-a-vyzkum/700-s-kybersikanou-mazkusenost-vice-jak-51-procent-deti.

Zavoralová, L. (2015). Prevence užívání návykových látek u žáků 2. stupně základní školy. [Preventing Substance Abuse Among Pupils of 2nd Level of Elementary Schools]. Bachelor thesis. (thesis supervisor: PhDr. Václav Bělík, Ph.D.) Hradec Králové: Faculty of Education, University of Hradec Králové. 


\section{Authors}

PhDr. Václav Bělík, Ph.D.

Faculty of Education, University of Hradec Králové

Department of Social Pathology and Sociology

Rokitanského 62, 50003 Hradec Králové, The Czech Republic

vaclav.belik@uhk.cz

Mgr. et Mgr. Stanislava Hoferková, Ph.D.

Faculty of Education, University of Hradec Králové

Department of Social Pathology and Sociology

Rokitanského 62, 50003 Hradec Králové, The Czech Republic

stanislava.hoferkova@uhk.cz 